\title{
A Study of Ponticulus Posterior of Atlas: Incidence and Clinical Co- Relations
}

\author{
Navbir Pasricha', Eti Sthapak ${ }^{2}$, Rajan Bhatnagar ${ }^{3}$ \\ ${ }^{1}$ Associate Professor, Department of Anatomy, Dr. Ram Manohar Lohia Institute of Medical Sciences, Lucknow, ${ }^{2}$ Assistant Professor, Department of \\ Anatomy, Dr. Ram Manohar Lohia Institute of Medical Sciences, Lucknow, ${ }^{3}$ Professor and Head, Department of Anatomy, Dr. Ram Manohar Lohia Institute \\ of Medical Sciences, Lucknow.
}

\section{Abstract}

Introduction: The posterior ponticulus or foramen arcuale is caused due to ossification of the connective tissue around the vertebral artery (VA). Formation of a complete foramen may disturb normal functioning of VA. Aims and Objectives: The study was done to investigate the incidence of ponticulus posterior in dry atlas vertebrae. Subjects and Methods: 50 dry human atlas vertebrae were examined from the bone collections in Dr RML Institute of Medical Sciences, Era's Lucknow medical college and Saraswati Dental College, Lucknow. The presence of ponticulus posterior was looked for and documented with photographs. Results: The presence of this accessory foramen on the dorsal arch was the only anomaly found in these vertebrae. The study showed the presence of a unilateral foramen in two vertebrae and one vertebra showed the anomaly bilaterally out of these one was a completely occluded ponticulus with an incidence of $6 \%$. Conclusion: The study provides evidence about the incidence of ponticulus posterior in the North Indian population. The clinicians should be aware of the possibility of this foramen in patients complaining of headache, vertigo and vertebrobasiliar insufficiency.

Keywords: atlas, ponticulus posterior, foramen arcuale, vertebral artery.

Corresponding Author: Dr. EtiSthapak, Assistant Professor, Department of Anatomy, Dr. Ram Manohar Lohia Institute of Medical Sciences, Lucknow.

Received: December 2019

Accepted: December 2019

\section{Introduction}

In the atlas, there is a groove behind the superior articular process called as sulcus arteriae vertebralis for transmitting the vertebral artery and suboccipital nerve. Sometimes the groove is converted into a foramen by an osseous bridge, which is given many names. The other names given to this foramen are Pons posticus, retroarticular canal, foramen atlantoideumposterius, foramen sagitale, kimmerle anomaly and retrocondylar bony foramen. ${ }^{[1]}$ The posterior arch of the atlas which is actually the lamina of other vertebrae is longer than the anterior arch. The posterior atlanto-occipital membrane is attached to the superior border of the posterior arch. This membrane is deficient at the lateral border through which the vertebral artery and first cervical nerve passes. ${ }^{[2]}$ The posterior ponticulus or foramen arcuale is caused due to ossification of the connective tissue around the vertebral artery (VA) or by some theories due to late ossification of lower edge of antlanto-occipital membrane. ${ }^{[3]}$ It has also been considered as a regressive primitive structure due to higher prevalence in lower primates. ${ }^{[1,4-6]}$ Formation of a complete foramen may disturb normal functioning of VA. The VA is vulnerable to compression at the atlantoaxial joint during head rotation, and the additional compression caused by ponticulus posterior may predispose VA to injury leading to vertigo, vertebrobasilar insufficiency, neck pain and cervicogenic headache. ${ }^{[4]}$ If the posterior ponticulus is mistaken for a broad posterior arch of the atlas during screw placement in the lateral mass of $\mathrm{C} 1$ one may injure the vertebral artery. ${ }^{[7]}$ Another factor for pressure over the VA which may cause reduction of its cross-sectional area and compromised blood supply could be extreme rotational movement caused due to a therapeutic manipulation. In case of these manipulations or extreme flexed positions of the neck as in some operative procedures if there is no prior knowledge of an extra foramen which may be compromising the flow of the VA the patient may be at risk of going into a Posterior cerebral ischaemia, ${ }^{[8]}$ so it is imperative that the incidence of ponticulus posterior in a given geographical population be studied.

\section{Aims and Objectives}

The study was done to investigate the incidence of ponticulus posterior in dry atlas vertebrae in Lucknow region.

\section{Subjects and Methods}

50 dry human atlas vertebrae were examined from the bone collections in Dr RML Institute of Medical Sciences, Era's Lucknow Medical College and Saraswati Dental college Lucknow. The vertebrae were thoroughly examined to 


\section{Pasricha et al; Panticulus pasteriar of Atlos}

ensure that they were intact and free from osteophytes or metatstatic tumors. The presence or absence of a complete or partial ponticulus posterior was looked for on the superior surface of the posterior arch and documented with photographs.

\section{Results \& $D$ iscussion}

50 Atlas vertebrae were examined for any abnormality. Two vertebrae showed extra foramen unilaterally (both on the left side). One vertebra had bilateral ponticulus posterior and out of these one (right side) was a completely occluded ponticulus. The presence of this accessory foramen on the dorsal arch was the only anomaly found in these vertebrae. None of our vertebrae showed partial ponticulus posterior. The incidence of presence of unilateral foramen was $4 \%$ and bilateral ponticulus posterior was only $2 \%$. If we consider the total number of ponticulus posterior in the total sample of 50 vertebrae the incidence comes out to be $6 \%$.

\section{Ponticulus posterior}

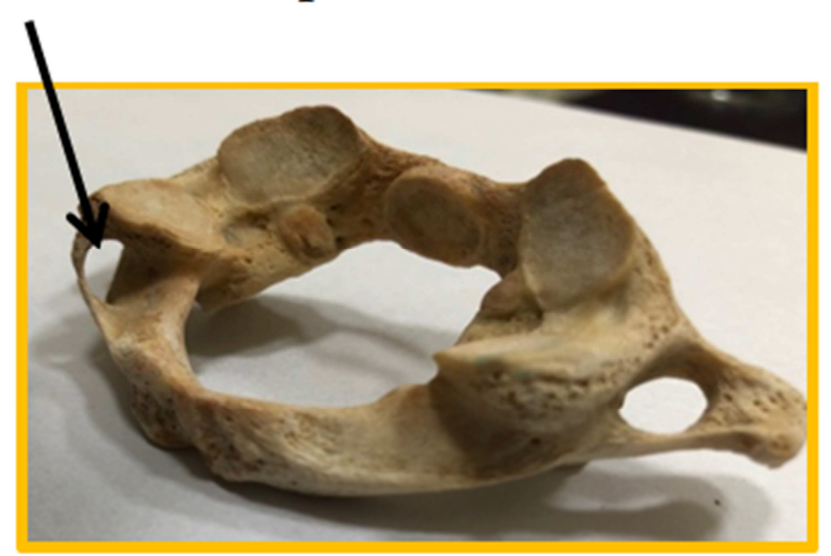

\section{Ponticulus Posterior}

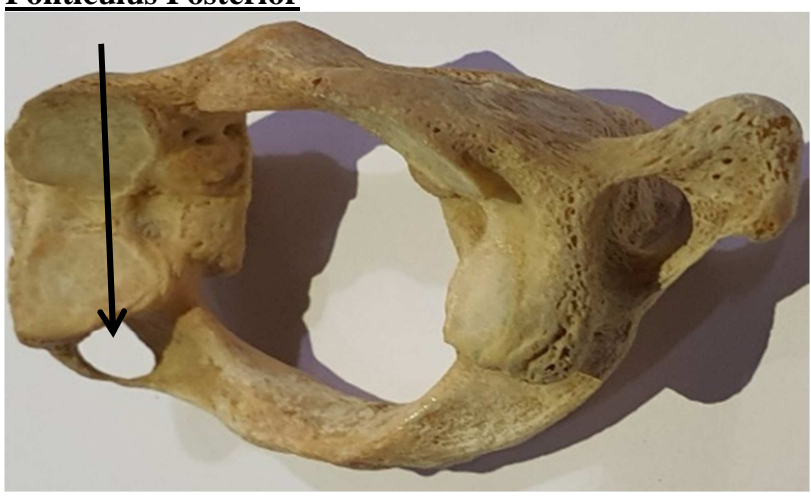

\section{Bilateral Ponticulus posterior}

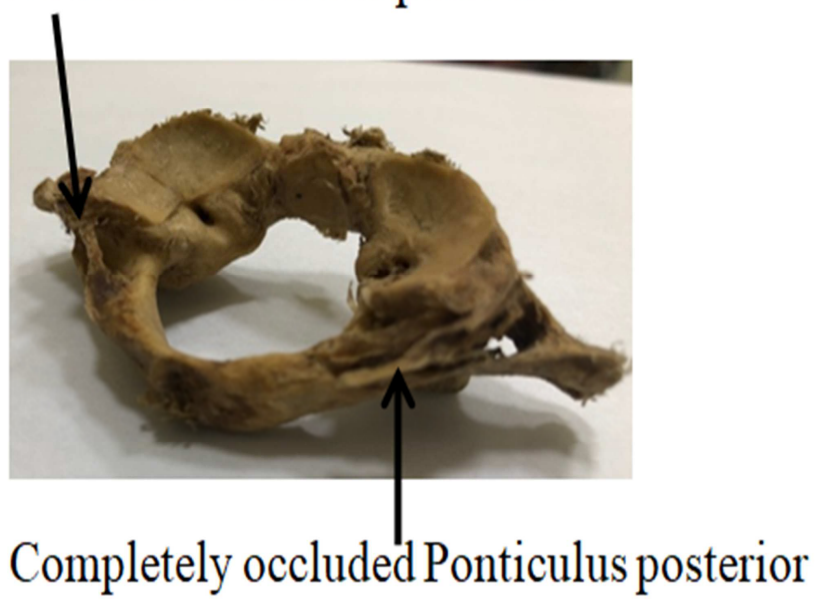

Table 1: Comparison of incidence of ponticulus posterior in different populations and studies

\begin{tabular}{|l|l|l|l|l|}
\hline Name of Author & Region & Incidence & Cadaveric/Radiologic & Sample size \\
\hline This study & Lucknow, U.P. & $6 \%$ & Dried bone & 50 \\
\hline Patel et al & Gujarat & $13 \%$ & Dried bone & 32 \\
\hline Krishnamurthy A et al & Mangalore & $8.33 \%$ & Dried bone & 1044 \\
\hline Sibel Cirpan et al & Turkey and black & $15.38 \%$ & Dried bone & 81 \\
\hline Ossenfort et al & $\begin{array}{l}\text { White } \\
\text { Americans }\end{array}$ & Dried Bone & 183 \\
\hline Taitz et al & Indian & $2.2 \%$ & Dried Bone & 139 \\
\hline Md Jawad Akhter et al & Bihar & $21.17 \%$ & Dried bone & 118 \\
\hline Taitz Cet al & Middle eastern & $7.4 \%$ & Dried Bone & 187 \\
\hline Manjunath KY & South Indian & $11.7 \%$ & Dried Bone & 60 \\
\hline Dhall U et al & Haryana & $37.83 \%$ & Dried Bone & 148 \\
\hline Gupta C et al & Manipal & $5.70 \%$ & bone & 55 \\
\hline Myoung Soo Kim & Korea & $10.5 \%$ & 3D CT & 108 \\
\hline Tubbs RS & Unknown & $5 \%$ & Cadaveric & 60 \\
\hline Ahmet Kavakh & Anatolian & $2.3 \%$ & Dried Bone & 86 \\
\hline
\end{tabular}

\section{Discussion}

The atlas vertebra articulates above with the occipital condyles of the skull forming the atlanto-occipital joint and below with the axis forming the atlanto-axial joint. These joints provide for wide range of movements, including flexion, extension, lateral movements and rotation of the neck. Various radiologic and surgical manoeuvres require sufficient movement of the neck including extension. Dental procedures and operative procedures like cleft palate require full extension of the neck. In case of such manipulations an undetected ponticulus posterior can lead to compression of the vertebral artery passing through this compromised space. Brown and Verheyden have quoted a singular case of cleft palate operation on a one-year child who landed up with 
posterior fossa infarction after the procedure. ${ }^{[9]}$ They advocated that neck extension should be minimised and also in light of the above case it is imperative that the surgeon be familiar with the possibility of a foramen arcuale or ponticulus posterior which can cause vertebrobasilar insufficiency.

Different populations show a varying prevalence rate (4.4$37.8 \%$ ) with high ranges among North Americans and Europeans (11.3-11.2\%) and in a study in Haryana region showing $37.8 \% .^{[10,11]}$ Ponticulus posterior has otherwise been reported to have the lowest frequency in Indians and South Koreans and highest in Britishers. ${ }^{[12-14]}$ Our studies shows a very low incidence comparable to the study of Gupta et al done in the Manipal region8.As can be seen in [Table 1] different studies done on dry bone, cadavers and CT Scan show much variation in the incidence in different populations, could be due to different study material, inherent variations in incidence based on populations or the number of sample size. The authors wished to have a greater sample size to give a better picture representative of the population. Also, remarkably, compared to study of Krishnamurthy et $a l,{ }^{[15]}$ the authors did not observe any incomplete ponticulus posterior. Similar to our study, a study conducted by Patel did not observe an incomplete posterior ponticulus. ${ }^{[16]}$ A completely occluded ponticulus posterior which was observed could not be found in any literature search. Although this observation was seen in a dry bone but it can be concurred that it would have lead to disruption in blood flow in the vertebral artery leading to ischaemic episodes and verebrobasilar insufficiency.

A meta-analysis conducted by Pekala et al in 2017, ${ }^{[10]}$ concluded that the ponticulus posterior could be a possible cause for headaches and migraines. They have said that ponticulus posterior can cause tension type headaches, migraines with or without aura, neuralgias, cervicogenic headaches, and may also be a cause of Barre- Lieou syndrome with symptoms of retro-orbital pain, headache, disturbances of vision, swallowing and phonation. These symptoms may be due to compression of sympathetic plexus around the vertebral artery. ${ }^{[17]}$ Ponticulus posterior may also cause vertigo, diplopia, lacrimation, neck pain, epilepsy, Meniere syndrome and acute hearing loss.

\section{Conclusion}

The study provides evidence about the incidence of ponticulus posterior in the North Indian population. The clinicians should be aware of the possibility of this foramen in patients complaining of headache, vertigo and vertebrobasiliar insufficiency.Physicians should consider this possibility in cases of migraine, neurosensory type hearing loss, unexplained shoulder/arm pain. Cervical spine radiography is a simple diagnostic tool to indicate the presence of arcuate foramen/ponticulus posterior and should be routinely undertaken for patients requiring screw placements in the lateral mass of the atlas.

\section{References}

1. Tubbs RS, Johnson PC, Shoja MM, Loukas M, Oakes WJ. Foramen arcuale: anatomical study and review of the literature. J Neurosurg Spine 2007;6:31-4. https://doi.org/10.3171/spi.2007.6.1.6.

2. Gray's Anatomy, Elsevier Ltd, Standring, 2005, 39th edition: 744745

3. Asvat R (1994) The incidence of posterior atlas bridging in a black and white south African samples. J Anal 184:437

4. Wight $\mathrm{S}$, Osborne N, Breen AC. Incidence of ponticulus posterior of the atlas in migraine and cervicogenic headache. J Manipulative PhysiolTher 1999;22:15-20. https://doi.org/10.1016/S01614754(99)70100-2.

5. Hasan M, Shukla S, Shakil Siddiqui M, Singh D. Posterolateral tunnels and ponticuli in human atlas vertebrae. J Anat 2001;199:33943. https://doi.org/ 10.1017/S0021878201008007.

6. Unur E, Erdogan N, Ulger H, Ekinci N, Özturk O. Radiographic incidence of complete arcuate foramen in turkish population. ErciyesTipDerg 2004;26:50-4.

7. Young JP, Young PH, Ackerman MJ, Anderson PA, Riew KD, The ponticulusposticus: implications for screw insertion into the first cervical lateral mass, J Bone Joint Surg Am, 2005,87 (11): 24952498.

8. C.Gupta, P.Radhakrishnan, V.Palimar, A.S D'souza, N.L. Kiruba, A quantitative analysis of atlas vertebrae and its abnormalities, J. Morphol. Sci., 2013,vol. 30, no.2, p. 77-81.

9. M.Brown and C.Verheyden. Posterior fossa infarction following cleft palate repair and the arcuate foramen. Plastic and Reconstructive surgery.11/2009; 124(5): 237-9.

10. Pekala PA, Henry BM, Pekala JR, Hsieh WC, Vikse J, Sanna B, et al: Prevalance of foramen arcuale and its clinical significance: a met analysis of 55,985 subjects. J Neurosurg Spine 2017; 27: 276-290.

11. Dhall U, Chabbra S, Dhall JC, Bilateral asymmetry in bridges and superior articular facets of atlas vertebra. J Anat Soc India (1993) Vol. 42: 23-27.

12. Taitz C, Nathan H. Some observations on the posterior and lateral bridging of the atlas. Acta Anat, 1986, Vol. 127: 212-217

13. Kim MS, Anatomical variant of Atlas: arcuate foramen, occipitalization of atlas and defect of posterior arch of atlas. J Korean Neurosurg Soc, 2015 Vol. 58 (6): 528-533.

14. Lamberty BG, Zivanovic S, The retro articular vertebral artery ring of the atlas and its significance, Acta Anat 1973, Vol. 85: 113-122.

15. KrishnamurthyA, Nayak SR, Khan S et al, Arcuate foramen of atlas: incidence, phylogenetic and clinical significance. Rom J MorpholEmbryol, 2007, Vol. 48(3): 263-266.

16. Patel Dinesh K, Shinde Amol A, Roy Nilanjan, Manvikar PR, Bharambe V, A study of foramen of arcuale in atlas vertebra: incidence and clinical correlations, Int J Cur Res Rev 2015, Vol 7 (20): 9-11.

17. O. Cakmak, E. Gurdal, G.Ekinci, E. Yildiz, S, Cavdar, Arcuate foramen and its clinical significance, Saudi Med J, 2005, 26(9): 1409-1413.

Copyright: () the author(s), publisher. Academia Anatomica International is an Official Publication of "Society for Health Care \& Research Development". It is an open-access article distributed under the terms of the Creative Commons Attribution Non-Commercial License, which permits unrestricted non-commercial use, distribution, and reproduction in any medium, provided the original work is properly cited.

How to cite this article: Pasricha N, Sthapak E, Bhatnagar R. A Study of Ponticulus Posterior of Atlas: Incidence and Clinical Co-Relations. Acad. Anat. Int. 2019;5(2):78-80.

DOI: dx.doi.org/10.21276/aanat.2019.5.2.21

Source of Support: Nil, Conflict of Interest: None declared. 